\title{
Base Composition of Deoxyribonucleic Acid from Spirillum volutans, $S$. serpens and $S$. itersonii
}

\author{
By J. A. COLE \\ Department of Biochemistry, The University of Birmingham, \\ Birmingham, BI $52 T T$
}

(Accepted for publication 2 I April 1972)

INTRODUCTION

Spirillum volutans, $S$. serpens and $S$. itersonii have been placed in the same genus largely on the basis of cell physiology (Williams \& Rittenberg, 1957). Similarities other than their characteristic shape include the accumulation of poly $\beta$-hydroxybutyrate in cytoplasmic granules (Martinez, I963), the presence of a cytochrome-linked electron-transfer chain, and the absence of $a$-type cytochromes (Cole \& Rittenberg, I97I). However, S. itersonii differs from the other species in its ability to grow anaerobically with nitrate, and $S$. volutans is uniquely sensitive to oxygen (Williams \& Rittenberg, 1957; Wells \& Krieg, 1965). Although cell shape has traditionally been a highly weighted character in classification, its importance in relation to DNA base composition was recently challenged by Bøvre \& Holten (I970) who suggested that the rod-shaped Neisseria elongata should be included in a genus of cocci. Because of the biochemical differences between the three spirilla, their DNA base compositions have been determined. The results suggest that $S$. volutans, $S$. itersonii and S. serpens are not closely related.

\section{METHODS}

Spirillum volutans (Pringsheim), American Type Culture Collection number (ATCC) I 9553, S. serpens var. serpens, ATCC I 2683 and S. itersonii var. itersonii, ATCC I 2639 were obtained and cultured as described by Cole \& Rittenberg (197I). Escherichia coli $\mathrm{KI} 2$ W I 485 was obtained from J. W. T. Wimpenny, and Proteus mirabilis DNA was a gift from F. Priest.

The DNA isolation procedure was based on the methods of Marmur (I96I) and Saito \& Muira (I963). Pellets of frozen bacteria (3 g wet wt) were thawed, suspended in $25 \mathrm{ml}$ $0.5 \mathrm{M}-\mathrm{NaCl}$ and $0 . \mathrm{I}$ M-ethylenediamine tetraacetate, $\mathrm{pH} 8.0$, and incubated for $20 \mathrm{~min}$ at $37{ }^{\circ} \mathrm{C}$ with $2 \mathrm{mg} / \mathrm{ml}$ lysozyme. Sodium dodecyl sulphate $(0.5 \%$, w/v) and pronase $(50 \mathrm{mg} / \mathrm{ml})$ were added with gentle mixing, and the solution incubated at $37^{\circ} \mathrm{C}$ for $\mathrm{I} 6 \mathrm{~h}$. Two volumes of freshly distilled phenol-saturated with $0.015 \mathrm{M}$-trisodium citrate and $0.15 \mathrm{M}-\mathrm{NaCl}$ (SSC) - were added and the flask shaken for $20 \mathrm{~min}$ at $0{ }^{\circ} \mathrm{C}$. After centrifuging, the nucleic acids were precipitated from the aqueous layer by adding two volumes of ethanol at $0{ }^{\circ} \mathrm{C}$. The fibrous precipitate was dissolved in SSC and incubated with deoxyribonuclease-free ribonuclease $\left(50 \mu \mathrm{g} / \mathrm{ml}\right.$ for $30 \mathrm{~min}$ at $\left.37^{\circ} \mathrm{C}\right)$. The extraction with phenol was repeated, and the clarified aqueous layer added to 10 vol ethanol at $0{ }^{\circ} \mathrm{C}$. Strands of DNA were spooled on a glass rod, washed successively in $70 \%, 80 \%$ and $90 \%(\mathrm{v} / \mathrm{v})$ ethanol, redissolved in $0 . \mathrm{I}$ SSC and dialysed exhaustively against $0 \cdot$ I SSC. The ratio of the extinctions at $257 \mathrm{~nm}$ and $280 \mathrm{~nm}$ was usually in the range $\mathrm{I} \cdot 9$ to $2 \cdot \mathrm{I}$. Samples with ratios below $\mathrm{I} \cdot 8$ were further purified by precipitating them with $0.7 \mathrm{vol}$ cold isopropanol, and redissolving them in 0.1 SSC. 
Table I. Thermal denaturation, buoyant density and GC content of DNA from Spirillum volutans, $S$. serpens and $S$. itersonii

\begin{tabular}{|c|c|c|c|c|}
\hline Organism & $T_{m}{ }^{*}$ & $\begin{array}{c}\% \text { GC calculated from } \\
\text { mean } T_{m}\end{array}$ & Buoyant density $\uparrow$ & $\begin{array}{l}\% \text { GC calculated from } \\
\text { buoyant density } \neq\end{array}$ \\
\hline tans & $67 \cdot 2 ; 66 \cdot 9$ & $32 \cdot 2$ & $\mathrm{I} \cdot 697$ & $36 \cdot 3$ \\
\hline S. serpens & $73 \cdot 2 ; 73 \cdot 4$ & $47 \cdot 4$ & $I \cdot 709$ & $48 \cdot 8$ \\
\hline S. itersonii & $78 \cdot 1 ; 78 \cdot 2$ & $59 \cdot 3$ & $I \cdot 72 I$ & $61 \cdot 2$ \\
\hline
\end{tabular}

* DNA dissolved in 0.1 SSC at a concentration of $20 \mu \mathrm{g} / \mathrm{ml}$ was contained in $4 \mathrm{ml}$ stoppered quartz cuvettes. The optical density at $260 \mathrm{~nm}$, measured in a Gilford 2000 attachment to a Beckman DU spectrophotometer, and the temperature in the cuvette chamber were recorded at $15 \mathrm{~s}$ intervals. The temperature of the circulating water was increased continuously by $0 \cdot 2{ }^{\circ} \mathrm{C} / \mathrm{min}$.

$\dagger$ Duplicates differed only in the fourth decimal figure.

$\$$ Calculated from the relationship: \% GC $=1038 \cdot 47(p-\mathrm{I} \cdot 66 \mathrm{I}$ ) $)($ De Ley, 1970).

The guanine plus cytosine mole fraction (GC content) was determined from the thermal denaturation profile of DNA dissolved in 0.I SCC (Marmur \& Doty, I962). The mid-point of the profile $\left(T_{m}\right)$ was estimated and the GC content derived from the equation:

$$
\% \mathrm{GC}=2 \cdot 44\left(T_{m}-53.9\right) \quad \text { (Mandel \& Marmur, I968). }
$$

Escherichia coli $\mathrm{KI} 2$ DNA with a $T_{m}$ of $74.5{ }^{\circ} \mathrm{C}$ in $0 . \mathrm{I}$ SSC was included as an internal standard with each batch of determinations.

GC contents derived from $T_{m}$ measurements were confirmed by determining the buoyant densities of the DNA in CsCl with a Beckman Model E Analytical Ultracentrifuge (Mandel, Schildkraut \& Marmur, I968). Escherichia coli K I2 DNA (buoyant density I.710) or Proteus mirabilis DNA (buoyant density $\mathrm{I} \cdot 700$ ) was included in each run as an internal standard.

\section{RESULTS AND DISCUSSION}

The GC contents of DNA from three spirilla were calculated from $T_{m}$ and buoyant density measurements (Table I). Spirillum volutans DNA melted at a much lower temperature than $S$. itersonii DNA, and an intermediate $T_{m}$ was obtained for $S$. serpens DNA. The more precise bouyant density measurements gave slightly higher GC contents than the $T_{m}$ measurements, but confirmed the large differences between them $(36 \%, 49 \%$ and $6 \mathrm{I} \% \mathrm{GC}$ for $S$. volutans, S. serpens and $S$. itersonii respectively; Table I).

Although similarity in GC content does not necessarily indicate genomic similarity, differences are more significant. De Ley (1969) has calculated that DNA samples which differ in GC content by more than $20 \%$ have practically no identical nucleotide sequences. Spirillum volutans and $S$. itersonii are therefore probably unrelated. A similar conclusion can be drawn from the GC contents of S. anum DNA (28\%; Marmur, Falkow \& Mandel, 1963) and $S$. serpens DNA. On the basis of these GC content measurements, it appears that the taxonomy of the genus Spirillum requires revision.

I am grateful to Professor S. C. Rittenberg for drawing my attention to the Ph.D. thesis of J. S. Wells (Virginia Polytechnic Institute, Blacksburg, Virginia, U.S.A.) in which $T_{m}$ determinations for various spirilla are reported. The GC contents calculated from these data are slightly higher than those derived from buoyant density determinations, but confirm the wide range within the genus. 


\section{REFERENCES}

Bøvre, K. \& Holten, E. (1970). Neisseria elongata sp. nov., a rod-shaped member of the genus Neisseria. Re-evaluation of cell shape as a criterion in classification. Journal of General Microbiology 6o, 67-75.

Cole, J. A. \& Rittenberg, S. C. (1971). A comparison of respiratory processes in Spirillum volutans, Spirillum itersonii and Spirillum serpens. Journal of General Microbiology 69, 375-383.

De LeY, J. (1969). Compositional nucleotide distribution and the theoretical prediction of homology in bacterial DNA. Journal of Theoretical Biology 22, 89-116.

DE LEY, J. (1970). Re-examination of the association between melting point, buoyant density, and chemical base composition of deoxyribonucleic acid. Journal of Bacteriology ror, 738-754.

Mandel, M. \& Marmur, J. (1968). Use of ultraviolet absorbance - temperature profile for determining the guanine plus cytosine content of DNA. Methods in Enzymology 12 B, 195-206.

Mandel, M., Schildkraut, C. L. \& Marmur, J. (I968). Use of CsCl density gradient analysis for determining the guanine plus cytosine content of DNA. Methods in Enzymology 12 B, I 84-195.

Marmur, J. (1961). A procedure for the isolation of deoxyribonucleic acid from microorganisms. Journal of Molecular Biology 3, 208-218.

Marmur, J. \& Doty, P. (I962). Determination of the base composition of deoxyribonucleic acid from its thermal denaturation temperature. Journal of Molecular Biology 5, I09-I 18.

Marmur, J., Falkow, S. \& Mandel, M. (1963). New approaches to bacterial taxonomy. Annual Review of Microbiology 17, 329-372.

Martinez, R. J. (I963). On the nature of the granules of the genus Spirillum. Archiv für Mikrobiologie 44, 334-343.

Saito, M. \& Muira, K. A. (1963). Preparation of transforming deoxyribonucleic acid by phenol treatment. Biochimica et biophysica acta 72, 619-629.

Wells, J. S. \& KRIEG, N. R. (1965). Cultivation of Spirillum volutans in a bacteria-free environment. Journal of Bacteriology 9o, 817-818.

Williams, M. A. \& RittenberG, S. C. (1957). A taxonomic study of the genus Spirillum Ehrenberg. International Bulletin of Bacteriological Nomenclature and Taxonomy. 7, 49-II0. 